\title{
Strategies for Reforming Korea's Labor Market to Foster Growth
}

\author{
Mai Dao*, Davide Furceri*, Jisoo Hwang** \\ Meeyeon Kim***, Tae-Jeong Kim****
}

The views expressed herein are those of the authors and do not necessarily reflect the official views of the IMF, IMF policy, or the Bank of Korea. When reporting or citing it, the authors' name should always be stated explicitly.

\footnotetext{
* International Monetary Fund, 700, 19th Street, N.W., Washington, D.C, USA. E-mail: MDao@imf.org, DFurceri@imf.org

** Former economist at the Bank of Korea. This research was completed while she was working at the Bank. Dr. Hwang is currently affiliated with Hankuk University of Foreign Studies. E-mail: Theji500@ gmail.com

*** Former economist at the Bank of Korea. Participated in this study while she was working at the Bank. E-mail: Gabriela.kim@gmail.com

**** Bank of Korea, 39, Namdaemun-Ro, Jung-Gu, seoul, Korea. E-mail: tjkim@bok.or.kr
}

This paper was prepared as part of a collaborative research effort between the IMF and BOK staff and published as an IMF Working Paper WP/14/137. 


\section{Contents}

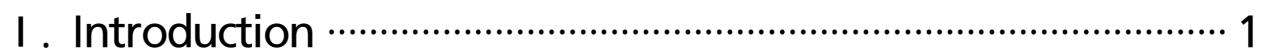

II. Boosting Female Labor Force Participation ……………....... 2

A. Empirical Analysis of the Determinants of Female Labor Force

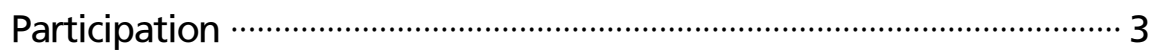

B. Policy Simulation …………………………………………………… 8

III. Raising Youth Employment and Labor Force …………….... 9

IV. Reducing Labor Market Dualism …………………….............. 14

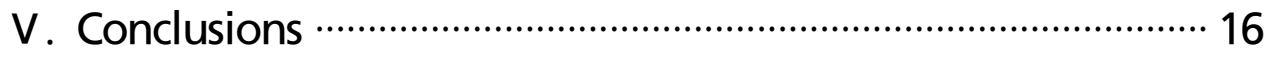

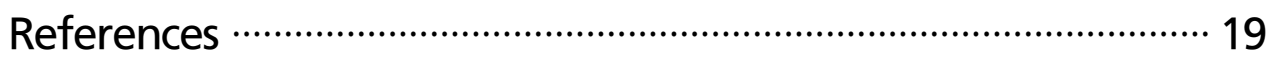

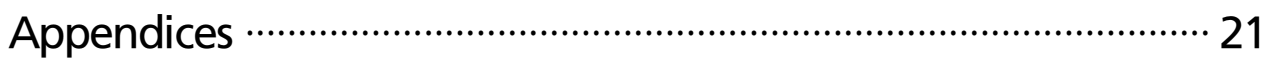




\section{Strategies for Reforming Korea's Labor Market to Foster Growth}

While the Korean unemployment rates are currently among the lowest in OECD countries, the labor market duality and the underemployment in some segments of the population are important labor market challenges, and factors contributing to lower potential growth. The paper shows the benefits of comprehensive policy reforms aimed at increasing labor force participation and youth employment and reducing duality are likely to be considerable in the medium term.

Keywords: labor market duality, female labor force participations, youth employment, reforms

JEL Classification: D04, D78, J08 


\section{I . Introduction}

Despite the deceleration in output growth, unemployment rates have decreased over the last decade. The overall unemployment rate declined from about $4 \frac{1}{2}$ percent in 2000 to about 3 percent in 2012, while youth unemployment decreased from about 11 percent to about 9 percent over the same period (see chart). While the Korean unemployment rates are currently among the lowest in OECD countries, the labor market duality (including the high share of non-regular workers) and the underemployment in some segments of the population (notably youth and women, see chart) are important labor market challenges, and factors contributing to lower potential growth.

This paper will provide an analysis of key labor market challenges to foster growth. ${ }^{1)}$ Our results suggest that the benefits of comprehensive structural reforms are likely to be considerable over the medium term. In particular, comprehensive policy reforms (such as: making the tax treatment of second earners in households compared with that of single earners more neutral; increasing childcare benefits; and facilitating more part-time work opportunities) aimed at reducing labor market distortions that inhibit labor force participation could increase female participation rates by about 8 percentage points over the medium term, which would reduce by one-third the gap between the rates of male and female participation. Similarly, policy actions-including targeted educational policies and retraining programs-to bring skill mismatches back onto a downward path before 2005 can increase the youth employment rate by 0.6 percentage points per year, which would boost it back up to its level from before the Asian crisis within 10 yers.

The rest of this paper is organized as follows. The next section will analyze the evolution of female labor force participation in Korea, also compare it to those in other OECD countries, and provide an empirical analysis of reforms that could boost female participation over the medium term. Section III will examine trends in youth employment, and assess the role of labor market mismatches as impediments to job creation. Section IV will discuss the labor market duality and associated policy remedies. Section $V$ will conclude by summarizing the main policy implications.

1) See Jain-Chandra and Zhang (2014) for a discussion of product market reforms to foster Korea's potential growth. 


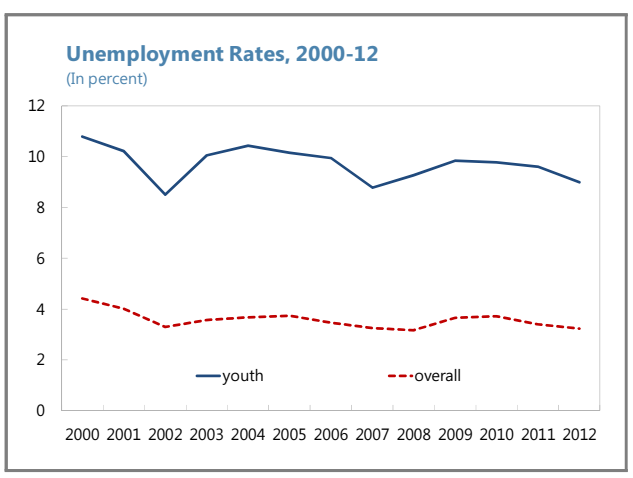

Source: OECD.

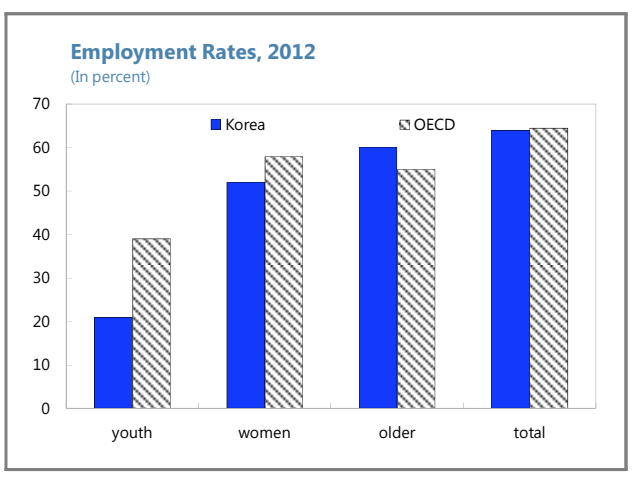

Source: OECD.

\section{Boosting Female Labor Force Participation}

Although female labor force participation has increased markedly over the last two decades, from about 50 percent in 1990 to 59 percent in 2011, significant gender differences in participation still persist. In particular, the male participation rates are still 221/2 percentage points higher than those for females, with the gender gap particularly high-above 35 percent-for age groups 25-29, 30-34 and 35 -39 (see chart).

Female participation rates are not only low compared to those for men in Korea, but also compared to female participation rates in other OECD countries. In particular, female labor force participation rates in Korea are among the lowest in the OECD (see chart), and almost 20 percentage points below those prevailing in the best performing countries (Iceland and the Nordic countries).

While part of the cross-country differences in participation rates may simply mirror differences in socio-cultural factors, removing policy distortions that prevent female participation is a key to fostering growth and reducing inequality. First, higher female participation rates can increase the labor supply, offsetting downward pressures on it resulting from population aging, and thereby boost potential output over the medium term. Second, as preferences for female participation tend to be higher than the actual female participation rates, removing 

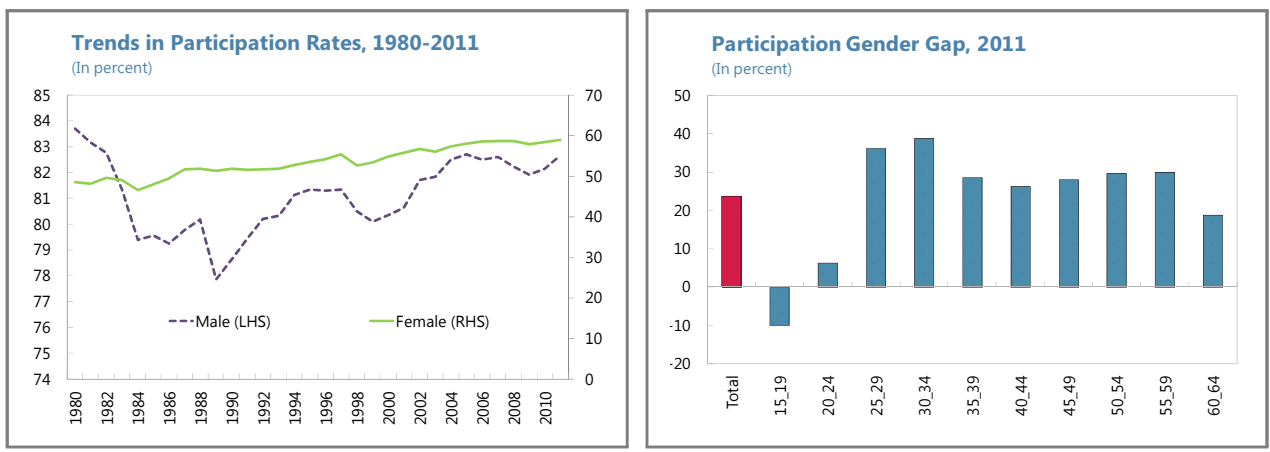

Source: OECD.

Source: OECD.

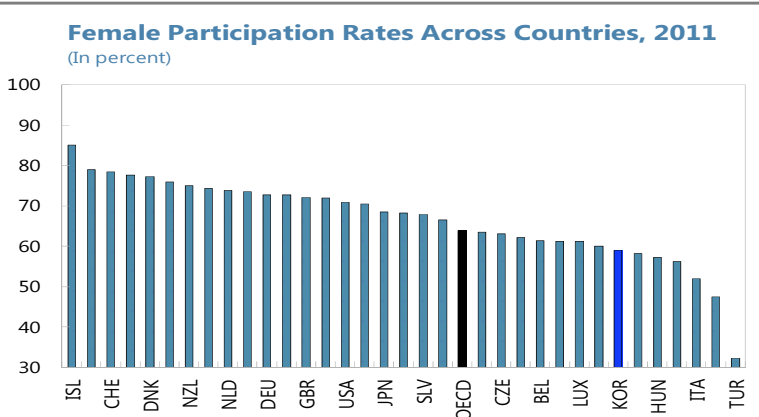

Source: OECD.

market distortions that inhibit female participation can lead to a higher level of aggregate income and welfare. Third, reducing the gap between male and female participation can help to reduce inequality.

The next section assesses the roles of various factors determining the pattern of female participation rates in Korea compared to those in other OECD countries, focusing on policy instruments that can be used to reduce market distortions and raise the female participation rates.

A. Empirical Analysis of the Determinants of Female Labor Force Participation

The determinants of labor force participation in Korea compared to other OECD countries are estimated using panel regressions for an unbalanced sample of 30 OECD countries over the period 1985-2011. In detail, the following differencein-difference equation is estimated: 


$$
L P R_{i t}=\alpha_{i}+\tau_{t}+\boldsymbol{\beta}^{\prime} \boldsymbol{X}_{i t}+\varepsilon_{i t}
$$

where $L P R$ indicates the female labor force participation rates; $\alpha_{i}$ are the country fixed effects, which capture unobserved factors including socio-cultural ones; $\tau_{t}$ are time fixed effects which capture the impacts of common and country-specific unobserved shocks affecting the participation rates, and $X$ is a set of policy variables that have been found in the literature to be robust determinants of female participation (Jaumotte, 2003). In order to make the results country specific for Korea, all variables are considered as deviations with respect to Korea's ones. The set of explanatory variables include: (i) the tax wedges between second earners and single individuals (computed as the ratio of the tax on second earners to the average tax rate of a single individual with the same gross income); (ii) childcare benefits (calculated as the increase in household disposable income from childcare benefits); (iii) tax incentives to part-time work; (iv) public spending on pre-primary education; (v) social expenditures on families;2) (vi) the female and male unemployment rates; (vii) the wage gaps between males and females; (viii) the degrees of employment protection legislation (EPL); (vii) the numbers of children per woman (measured by the ratios of children aged $0^{-14}$ years to women aged $15^{-64}$ years); (viii) the female tertiary education rates; and (ix) the logs of GDP per capita. Additional variables which have been found to be typically associated with female participation rates, such as child subsidies and paid parental leave, have not been included due to limited time series availability for Korea. ${ }^{3)}$

2) Public expenditure on families is composed of: (i) Child-related cash transfers to families with children: including child allowances, with payment levels that in some countries vary with the ages of the children, and public income support payments during periods of parental leave; (ii) Public spending on services for families with children: direct financing and subsidizing of providers of childcare and early education facilities, public childcare support through earmarked payments to parents, public spending on assistance for young people and residential facilities, and public spending on family services, including centre-based facilities and home help services for families in need; and (iii) Financial support for families provided through the tax system: tax expenditures toward families including tax exemptions (e.g. income from childcare benefits that is not included in the tax base), child tax allowances (amounts for children that are deducted from gross income and not included in taxable income), child tax credits (amounts that are deducted from the tax liabilities).

3) Jaumotte (2003), based on a sample of 20 OECD countries (excluding Korea), found that childcare subsidies and parental leave have positive effects on female participation rates. 
The results from the estimation of equation 1 are reported in Table 1. In the first column of the table we present the results for the baseline specification, which includes both time and country fixed effects and focuses on the key policy determinants that have typically been found in the literature to affect female participation (Jaumotte, 2003). The main results are that: (i) the wedge between the tax rates of second earners and single individuals has a negative impact on female labor force participation;4) (ii) an increase in childcare benefits has a statistically significant and large impact in boosting female participation rates; (iii) tax incentives to part-time work tend to increase female participation; and (iv) an increase in the probability of being employed (proxied by unemployment outcomes for both males and females) tends to improve participation. In contrast, public spending on pre-primary education and public expenditure on families do not have significant impacts on female labor force participation in Korea compared to other countries. The results, particularly for the tax wedge and childcare benefits, are robust to different specifications, different sets of controls, and step-wise regression (columns II-VII).5) Finally, while endogeneity may be an issue, particularly for the measures of unemployment rates, the results are robust to endogeneity checks and Instrumental Variable regression (Table 2).

The results presented in Table 3 suggest that the effects of these variables vary across the different age groups. First, these policies do not seem to significantly affect participation for the age group 55-64. Second, while the tax wedge and childcare benefits affect female participation in all other age groups, part-time regulations seem to significantly affect participation only in women in the $25-39$ age group.

4) The tax wedge is computed as the ratio of Tax second earner to Tax single individual. The tax second earner is calculated as: Tax second earner $=1-\frac{(\text { Household Net Income })_{B}-(\text { Household Net Income })_{A}}{(\text { Household Gross Income })_{B}-(\text { Household Gross Income })_{A}}$ where A represents the case in which the wife does not earn any income and B the case in which the wife's gross earnings are 67 percent that of the Average Production Worker (APW). The tax single individual is computed using the same formula, although in this situation the household is only made up of the individual.

5) Note that the specification with time fixed effects is equivalent to a regression in which all variables are demeaned from Korea's ones. The results presented in Column II, which do not consider time fixed effects, are qualitatively similar, even though the effects of the tax wedge, childcare benefits and tax incentives to part-time are larger in absolute values. 
Finally, it is important to stress that, while policy actions can in principle boost female participation rates in Korea, much of the cross-country variation in female labor force participation is captured by country fixed effects, suggesting that unobserved factors including differences in socio-cultural factors and institutional features play the most important roles. The compelling question is then what would be the potential impacts of reforms aimed at reducing labor market distortions.

\section{Table 1. Determinants of Female Labor Force Participation}

\begin{tabular}{|c|c|c|c|c|c|c|c|}
\hline Indenondont variahlo & Baseli & line & Robus & stness ch & hecks & & \\
\hline Ident variable & $(1)$ & ( II) & ( III) & $(\mathrm{N})$ & $(\mathrm{V})$ & $(\mathrm{VI})$ & $(\mathrm{V} \|)^{\mathrm{a}}$ \\
\hline Tax second earner & $\begin{array}{c}-0.182^{* *} \\
(-2.12)\end{array}$ & $\begin{array}{c}-0.339^{* * *} \\
(-3.73)\end{array}$ & $\begin{array}{c}-0.230^{* *} \\
(-2.46)\end{array}$ & $\begin{array}{c}-0.189^{* *} \\
(-2.43)\end{array}$ & $\begin{array}{c}-0.264^{* * *} \\
(-3.19)\end{array}$ & $\begin{array}{c}-0.309^{* *} \\
(-2.25)\end{array}$ & $\begin{array}{c}-0.350^{* * *} \\
(-4.20)\end{array}$ \\
\hline Childcare benefits & $\begin{array}{c}0.389^{* *} \\
(2.18)\end{array}$ & $\begin{array}{c}0.448^{* *} \\
(2.06)\end{array}$ & $\begin{array}{c}0.467^{* *} \\
(2.30)\end{array}$ & $\begin{array}{l}0.263^{*} \\
(1.81)\end{array}$ & $\begin{array}{c}0.359^{* *} \\
(2.18)\end{array}$ & $\begin{array}{c}0.811^{* * *} \\
(3.15)\end{array}$ & $\begin{array}{c}0.559^{* * *} \\
(3.45)\end{array}$ \\
\hline Tax incentive to part time & $\begin{array}{c}0.281^{*} \\
(1.68)\end{array}$ & $\begin{array}{l}0.372^{*} \\
(1.80)\end{array}$ & $\begin{array}{l}0.179 \\
(0.98)\end{array}$ & $\begin{array}{l}0.216^{*} \\
(1.76)\end{array}$ & $\begin{array}{l}0.032 \\
(0.22)\end{array}$ & $\begin{array}{l}-0.513 \\
(-1.06)\end{array}$ & - \\
\hline Public spending on pre-primary education (log) & $\begin{array}{l}-0.002 \\
(-0.45)\end{array}$ & $\begin{array}{l}-0.005 \\
(-0.77)\end{array}$ & $\begin{array}{l}-0.002 \\
(-0.58)\end{array}$ & - & - & $\begin{array}{l}-0.005 \\
(-0.22)\end{array}$ & - \\
\hline Public expenditure on family (log) & $\begin{array}{l}0.005 \\
(0.40)\end{array}$ & $\begin{array}{l}0.011 \\
(1.37)\end{array}$ & $\begin{array}{l}-0.051 \\
(-0.84)\end{array}$ & - & - & $\begin{array}{l}0.015 \\
(0.57)\end{array}$ & - \\
\hline Male unemployment (log) & $\begin{array}{c}-0.030^{* *} \\
(-2.34)\end{array}$ & $\begin{array}{c}-0.041^{* * *} \\
(-3.56)\end{array}$ & $\begin{array}{c}-0.046^{* * *} \\
(-4.24)\end{array}$ & $\begin{array}{c}-0.046^{* * *} \\
(-3.88)\end{array}$ & - & $\begin{array}{c}-0.038^{*} \\
(-1.78)\end{array}$ & $\begin{array}{c}-0.041^{* *} \\
(-2.34)\end{array}$ \\
\hline Female unemployment (log) & $\begin{array}{c}-0.025^{* *} \\
(-2.24)\end{array}$ & $\begin{array}{l}-0.011 \\
(-0.91)\end{array}$ & $\begin{array}{l}-0.006 \\
(-0.52)\end{array}$ & $\begin{array}{c}-0.015^{*} \\
(-1.07)\end{array}$ & - & $\begin{array}{l}0.001 \\
(0.03)\end{array}$ & - \\
\hline Number of children (log) & $\begin{array}{l}0.068 \\
(0.57)\end{array}$ & $\begin{array}{c}0.041^{* * *} \\
(3.67)\end{array}$ & $\begin{array}{c}0.290^{* * *} \\
(4.10)\end{array}$ & - & - & $\begin{array}{l}0.324 \\
(0.88)\end{array}$ & - \\
\hline EPL $(\log )$ & - & - & - & - & - & $\begin{array}{l}-0.024 \\
(-0.23)\end{array}$ & - \\
\hline Wage gap (log) & - & - & - & - & - & $\begin{array}{l}-0.002 \\
(-0.17)\end{array}$ & - \\
\hline Female tertiary education (log) & - & - & - & - & - & $\begin{array}{l}-0.085 \\
(-0.82)\end{array}$ & - \\
\hline GDP per capita (log) & - & - & - & - & - & $\begin{array}{l}0.051 \\
(1.11)\end{array}$ & - \\
\hline Country-specific time trends & No & Yes & No & No & No & No & No \\
\hline Time FE & Yes & No & No & Yes & Yes & Yes & Yes \\
\hline $\mathrm{N}$ & 237 & 237 & 237 & 333 & 333 & 66 & 66 \\
\hline Adjusted $\mathrm{R}^{2}$ & 0.99 & 0.99 & 0.99 & 0.99 & 0.98 & 0.99 & 0.99 \\
\hline
\end{tabular}

Note: Country fixed effects included but not reported. T-statistics based on robust standard errors in parentheses.

a results based on stepwise regression. 


\section{Table 2. Determinants of Female Labor Force Participation, OLS vs. IV}

\begin{tabular}{|c|c|c|}
\hline \multirow{2}{*}{ Independent variable } & OLS & $\mathrm{IV}^{\mathrm{a}}$ \\
\hline & (I) & $(\|)$ \\
\hline Tax second earner & $\begin{array}{c}-0.339^{* * *} \\
(-3.73)\end{array}$ & $\begin{array}{l}-0.196^{* *} \\
(-1.99)\end{array}$ \\
\hline Childcare benefits & $\begin{array}{l}0.448^{* *} \\
(2.06)\end{array}$ & $\begin{array}{l}0.426^{* *} \\
(2.49)\end{array}$ \\
\hline Tax incentive to part time & $\begin{array}{l}0.372^{*} \\
(1.80)\end{array}$ & $\begin{array}{l}0.329^{*} \\
(1.94)\end{array}$ \\
\hline Public spending on pre-primary education (log) & $\begin{array}{l}-0.005 \\
(-0.77)\end{array}$ & $\begin{array}{l}-0.009 \\
(-1.00)\end{array}$ \\
\hline Public expenditure on family (log) & $\begin{array}{l}0.011 \\
(1.37)\end{array}$ & $\begin{array}{l}0.001 \\
(0.06)\end{array}$ \\
\hline Male unemployment (log) & $\begin{array}{l}-0.041^{* * *} \\
(-3.56)\end{array}$ & $\begin{array}{l}-0.026 \\
(-1.06)\end{array}$ \\
\hline Female unemployment (log) & $\begin{array}{l}-0.011 \\
(-0.91)\end{array}$ & $\begin{array}{l}-0.029 \\
(-1.00)\end{array}$ \\
\hline Number of children (log) & $\begin{array}{c}0.041^{* * *} \\
(3.67)\end{array}$ & $\begin{array}{l}0.064 \\
(0.52)\end{array}$ \\
\hline Kleibergen-Paap statistic ( $p$-value in parentheses) & - & $\begin{array}{c}19.864 \\
(0.02)\end{array}$ \\
\hline Hansen $J$ statistic ( $p$-value in parentheses) & - & $\begin{array}{l}5.946 \\
(0.65)\end{array}$ \\
\hline Country-specific time trends & Yes & No \\
\hline Time FE & No & Yes \\
\hline N & 237 & 237 \\
\hline Adjusted $\mathrm{R}^{2}$ & 0.99 & 0.99 \\
\hline
\end{tabular}

Note: Country fixed effects included but not reported. T-statistics based on robust standard errors in parentheses.

a Public expenditures on pre-primary education and family, number of children, and unemployment rates instrumented by their lagged values (up to 3 lags), as well as all exogenous variables of the model

Table 3. Determinants of Female Labor Force Participation, by Age Group

\begin{tabular}{lcccc}
\multicolumn{1}{c}{ Dependent variable } & $15-24$ & $25-39$ & $40-54$ & $55-64$ \\
Tax second earner & $-0.955^{* * *}$ & $-0.151^{*}$ & $-0.289^{* *}$ & -0.457 \\
& $(-2.05)$ & $(-1.72)$ & $(-2.52)$ & $(-1.61)$ \\
Childcare benefits & $2.603^{* *}$ & $0.474^{* *}$ & $0.523^{*}$ & $-0.472^{*}$ \\
\multirow{2}{*}{ Tax incentive to part time } & $(2.15)$ & $(2.06)$ & $(1.93)$ & $(-1.86)$ \\
& 0.300 & $0.462^{*}$ & 0.217 & 0.950 \\
Male unemployment (log) & $(0.41)$ & $(2.28)$ & $(0.92)$ & $(1.32)$ \\
& -0.031 & $-0.047^{* * *}$ & $-0.038^{* *}$ & 0.003 \\
Female unemployment $(\mathrm{log})$ & $(-0.53)$ & $(-4.47)$ & $(-2.20)$ & $(0.07)$ \\
Time FE & -0.020 & -0.003 & -0.009 & $-0.086^{*}$ \\
$\mathrm{~N}$ & $(-0.20)$ & $(-0.21)$ & $(-0.59)$ & $(-1.83)$ \\
Adjusted $\mathrm{R}^{2}$ & Yes & Yes & Yes & Yes \\
\hline
\end{tabular}

Note: Country fixed effects and the controls presented in Table 3 included but not reported. T-statistics based on robust standard errors in parentheses. 


\section{B. Policy Simulation}

In order to illustrate the potential impacts of policy measures on female participation, a number of policy scenarios can be simulated using the results of the estimated equation presented in the previous section. Before turning to the analysis, however, it is important to highlight the limitations of this approach. First, the results are sensitive to the uncertainties associated with the estimates of the effects of structural policies on labor force participation. Second, it assumes that it is possible to disentangle the effects of specific reforms, abstracting from the complementarity of these reforms and the appropriate sequence of implementation. Third, financing requirements associated with the simulated policy changes may imply a need for significant increases in (other) tax rates with repercussions on labor force participation. These general equilibrium effects have not been taken into account in the simulations, which therefore may give a biased picture of the effects of policy reforms (Jaumotte, 2003). With these caveats in mind, this analysis can still provide some indication of the magnitude of the effects of such reforms in boosting female labor force participation in Korea over the medium term.

The effects of structural reforms on Korea's female labor force participation are computed by simulating a convergence of policy settings toward those prevailing in benchmark countries, identified as those with the lowest restrictions. In detail, the potential female participation gains $\left(g_{i}\right)$ from these structural reforms are simulated as:

$$
g_{i}=\beta_{i}\left(I^{k}-I^{B}\right)
$$

where $\beta_{i}$ is, for each indicator $I$, the estimated parameter of the effect of structural reform on female labor force participation reported in the first column of Table 1 , and $I^{k}$ and $I^{B}$ are the values of the indicators in Korea and in the benchmark countries, respectively (see chart).

The adjacent chart presents the increases in female participation that can be achieved under various scenarios. The average participation gain from a reform in the tax treatment of second earners is about $1 / 2$ percentage point. Policies aimed at 

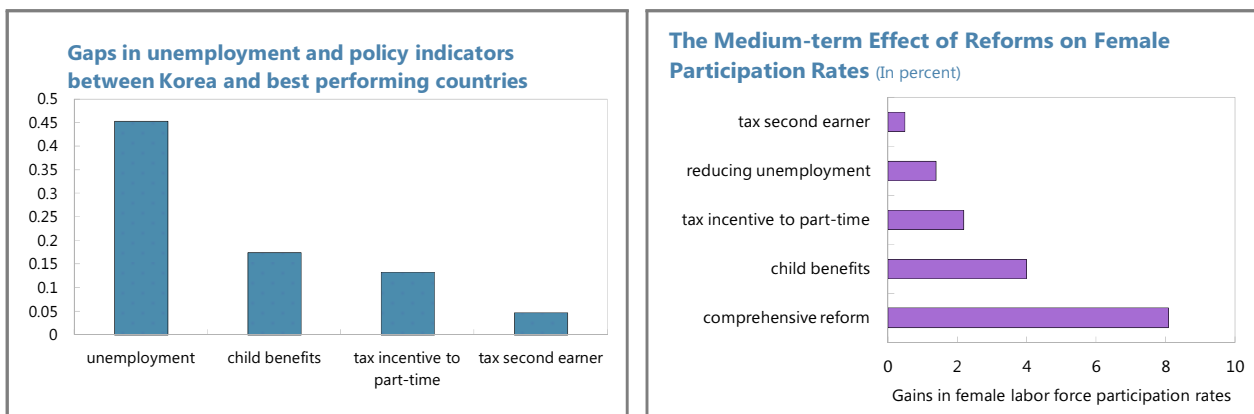

Note: Positive gaps for child benefits and tax Source: IMF staff calculations. incentives to part-time indicate that Korea performs worse than benchmark countries. Positive gaps for unemployment and tax second earners indicate that unemployment and tax on second earners are higher than in benchmark countries.

Source: OECD and IMF staff calculations.

reducing unemployment would lead to an increase of about 1.4 percentage points. Reform of the tax incentives to part-time work would result in an increase of about 2 percentage points. Finally, reforms aimed at closing the gap between Korea and the benchmark countries in terms of childcare benefits would result in a significant increase in participation of about 4 percentage points. Combining these scenarios, the results suggest that a comprehensive set of reforms aimed at reducing the distortions captured by these indicators would lead to an increase in female participation rates of about 8 percentage points over the medium term, which would imply a reduction of the gap between male and female participation of about 33 percent. ${ }^{6}$ )

\section{Raising Youth Employment and Labor Force}

Despite the decrease in youth unemployment observed over the last two decades, the youth employment rate in Korea remains relatively low compared to

6) As discussed earlier, the effect of a comprehensive set of reforms abstracts from reforms complementarity, and it implicitly assumes that the effect of reforms in single policy areas is addictive. 
those in other OECD countries. Indeed, the data on youth participation suggest that the main factor driving the lower unemployment rate for youth has been the decline in labor force participation. In particular, the youth participation rate has decreased steadily over the last two decades, from about 37 percent in 1994 to around 261/2 percent in 2012, one of the lowest in OECD countries (the average youth participation rate in the OECD is about $471 / 2$ percent).

Although the low youth participation rate may reflect the increasing rates of enrollment in tertiary education and military conscription ${ }^{7)}$, it also reflects the degree of labor market mismatch, which pushes young graduates to withdraw from the labor force as they fail to find opportunities matching their qualifications. The next section will analyze this issue, by constructing a measure of labor market mismatch and assessing its impact on youth employment.

\section{Labor Market Mismatch and Youth Employment}

To construct a measure of the degree of mismatch, we follow the methodology in Estevao and Tsounta (2011) and Peters (2000). The metric to proxy skill mismatches is the difference between the skill demand and skill supply in the economy. The skill mismatch index (SMI) is defined as:

$$
S M I_{t}=\sum_{j=1}^{3}\left(S_{j t}-M_{j t}\right)^{2}
$$

where workers' skills are divided into three levels, proxied by educational attainment: $1=$ low (less than high school), $2=$ semi (high school graduates), and $3=$ high skill (bachelor's degrees or higher). $S_{j t}$ stands for the supply of the skill level of $j$, measured by the share of the population with the corresponding educational attainment. Korea's population census is compiled every five years, and so to compute the annual skill level supplies, the data for the in-between years are

7) Bernal-Verdugo et al. (2012) show that military conscription is on the main factor affecting youth employment rates. 
interpolated. The skill demand $M_{j t}$ is computed as the share of employees in industries that have skill intensity $j$, where the employee data by industry is taken from the Korean Ministry of Employment and Labor (MOEL)'s survey at establishment. The skill intensity of each industry with a two-digit industrial code $\left(\mathrm{KSIC}^{8}\right)$ ) is based on that industry's skill intensity score in the base year (2006), which is the weighted average educational attainment of the employees in that industry.9) The skill intensity of industries calculated for Korea is provided in the appendix.

For a robustness check, another measure of skill-demand from industry is calculated based on occupation data. Autor et al. (2003) grouped occupations into three categories-routine manual, routine cognitive, and non-routine cognitive. We use the employment statistics by occupation based on the MOEL's survey at establishment. The nine occupations (one-digit $\mathrm{KSCO}^{10}$ ) specifications) are divided into three categories (Table 4), exactly the same as in Autor et al. (2003). We apply this categorization and compute the ratio of the workers employed in each category to the total number of workers.

The chart presents the evolution of the indicator of skill mismatches constructed using both 60 2-digit industries and nine occupations. The chart shows that mismatches decreased considerably immediately after the Asian crisis, but have leveled off since 2005. While the indicator of mismatches does not seem to be related with the evolution of unemployment (either overall or youth, see chart), it is strongly associated with the youth employment rate (see chart).

8) KSIC stands for Korean Standard Industrial Classification. The following three industries are excluded from the analysis: Public Administration and Defense; Compulsory Social Security (KSIC code: 76); Private Households with Employed Persons (KSIC code: 95), and Extra-Territorial Organizations and Bodies (KSIC code: 99).

9) Employees younger than 18 years of age or older than 64 are excluded from skill intensity computation, and the weights of 1, 2 and 3 are given to low-, middle- and high-skilled employees, respectively. We compute the average and standard deviations of the skill intensity scores; industries with scores higher than the total average plus 0.67 standard deviations are classified as high-skilled. If the skill intensity score is lower than the total average minus $0.67^{*}$ standard deviation, the corresponding industry is grouped as low-skilled. All other industries are classified as middle-skilled.

10) KSCO stands for Korean Standard Classification of Occupations. This analysis adopts the KSCO data revised in 2007 ( $7^{\text {th }}$ revision). 


\section{Table 4. Skill Levels, by Occupation}

\begin{tabular}{c|l|c|c|c}
$\begin{array}{c}\text { KSCO } \\
\text { Occupation } \\
\text { Code }\end{array}$ & \multicolumn{1}{|c|}{ Occupation title } & $\begin{array}{c}\text { Non-routine } \\
\text { Cognitive } \\
\text { (NC) }\end{array}$ & $\begin{array}{c}\text { Routine } \\
\text { (R) }\end{array}$ & $\begin{array}{c}\text { Non-routine } \\
\text { Manual } \\
\text { (NM) }\end{array}$ \\
\hline 1 & Managers & $\times$ & & \\
2 & Professional and Related Workers & & $\times$ & \\
3 & Clerks & & & $\times$ \\
4 & Service Workers & & $\times$ & \\
5 & Sales Workers & & $\times$ & \\
6 & Skilled Agricultural, Forestry and Fishery Workers & & $\times$ & \\
7 & Craft and Related Trade Workers & & \\
8 & Equipment, Machine Operating and Assembling Workers & & & \\
9 & Elementray Workers & & & $\times$ \\
\hline
\end{tabular}

The weak (strong) association with youth unemployment (employment) is confirmed when we regress unemployment (employment) against our measure of labor market mismatches and several control variables (Tables 5-6) -including current and lagged GDP growth, a time trend, and a dummy variable that takes a value equal to one during the Asian crisis. In particular, the results suggest that a 10 percent decrease in labor market mismatches could increase the employment rates by about 6 to 14 percentage points over the medium term. In other words, policy actions bringing skill mismatches back onto a downward path before the mid-2000s can increase the youth employment rate substantially.

Key areas of intervention to reduce labor market mismatches include: (i) improving social dialogue to identify the gaps between school curricula and business needs; (ii) enhancing technical vocational education and training, including apprenticeships; (iii) introducing mechanisms for early identification of potential labor force leavers to encourage them to access other employment, education or training opportunities; (iv) including job-search techniques in school curricula; and (v) improving young people's access to information on career opportunities. 

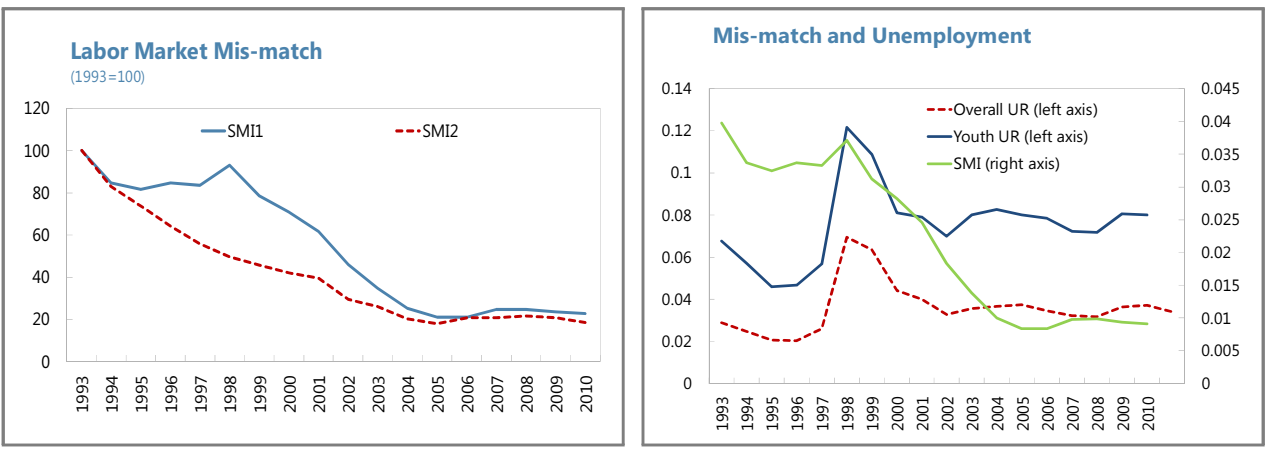

Note: SMI1 based on 60 2-digit industries and Source: IMF staff calculations.

SMI2 based on 9 occupations. Lower values

stand for smaller mismatch.

Source: IMF staff calculations.

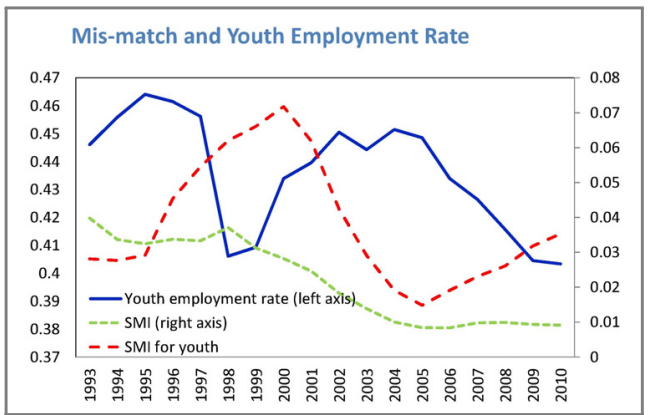

Source: IMF staff calculations.

Table 5. Mismatches and Labor Market Outcomes

\begin{tabular}{ccccc} 
& UR & YUR & ER & ER \\
$\ln (S M I)_{t}$ & 10.15 & 0.687 & $-1.348^{* *}$ & $-0.560^{*}$ \\
& $(0.593)$ & $(0.558)$ & $(0.485)$ & $(0.282)$ \\
$\Delta \ln (G D P)_{t}$ & $-0.478^{*}$ & $-0.550^{* *}$ & $0.362^{*}$ & -0.122 \\
$\Delta \ln (G D P)_{t-1}$ & $(0.241)$ & $(0.230)$ & $(0.196)$ & $(0.204)$ \\
Time trend & $-0.577^{* *}$ & $-0.592^{* *}$ & $0.495^{*}$ & -0.269 \\
Dummy (98,99) & $(0.267)$ & $(0.258)$ & $(0.232)$ & $(0.294)$ \\
$R^{2}$ & 0.120 & 0.094 & -0.115 & $-0.116^{*}$ \\
& $(0.125)$ & $(0.119)$ & $(0.101)$ & $(0.065)$ \\
& no & no & no & yes \\
\hline
\end{tabular}

Note: UR=overall (15-64 years old) unemployment rate; YUR= youth (15-29 years old) unemployment rate; $E R=$ overall employment/population ratio. Dummy $(98,99)$ equals 1 for years 1998 and 1999. A constant is included in all regressions. The standard errors in parentheses are robust to heteroskedasticity, no autocorrelation in residuals is detected with the Lagrange test, and $*, * *$ and $* * *$ denote significances of $10 \%, 5 \%$ and $1 \%$, respectively. 


\section{Table 6. Mismatches and Youth Employment Rates}

\begin{tabular}{cccc} 
& YER & YER & YER \\
$\ln (S M I)_{t}$ & $-1.455^{* * *}$ & $-2.122^{* * *}$ & $-1.086^{* * *}$ \\
& $(0.284)$ & $(0.393)$ & $(0.276)$ \\
$\ln (S M I)_{t-1}$ & & $0.828^{*}$ & \\
& & $(0.461)$ & 0.046 \\
$\Delta \ln (G D P)_{t}$ & $0.272^{* *}$ & $0.238^{* *}$ & $(0.129)$ \\
& $(0.105)$ & $(0.095)$ & $(0.204)$ \\
$\Delta \ln (G D P)_{t-1}$ & $0.408^{* * *}$ & $0.448^{* * *}$ & 0.052 \\
Time trend & $(0.100)$ & $(0.119)$ & $(0.220)$ \\
Dummy (98,99) & $-0.33)^{* * *}$ & $-0.298^{* * *}$ & $-0.330^{* * *}$ \\
$R^{2}$ & $(0.119)$ & $(0.069)$ & $(0.062)$ \\
& No & No & Yes \\
\hline
\end{tabular}

Note: YER= youth (15-29 years old) employment/population ratio. Dummy $(98,99)$ equals 1 for years 1998 and 1999. A constant is included in all regressions. The standard errors in parentheses are robust to heteroskedasticity, no autocorrelation in the residuals is detected with the Lagrange test, and $*, * *$ and $* * *$ denote significances of $10 \%, 5 \%$ and $1 \%$, respectively.

\section{Reducing Labor Market Dualism}

Regular workers account for less than 50 percent of total employees in Korea (see chart). Among non-regular workers-which include (i) temporary workers, (ii) daily workers, (iii) the self-employed, and (iv) unpaid family workers-the largest proportions are those of temporary workers and the self-employed.

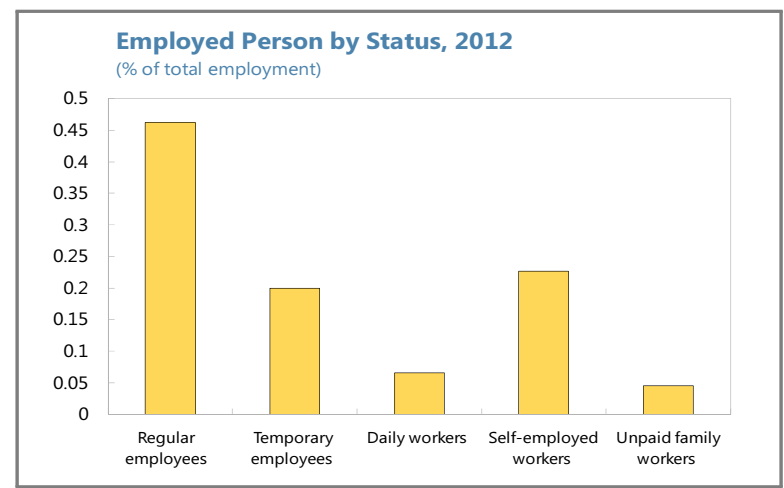

Source: Statistics of Korea 
Non-regular workers are typically less educated (the share of non-regular workers with tertiary education is about 30 percent, compared to that of more than 50 percent for regular workers), tend to receive less social insurance coverage (about 40 percent of non-regular workers are covered by employees' pension schemes and health insurance, compared to about 80 percent for regular workers) and are characterized by having more flexible contracts. Overall, non-regular workers are mostly concentrated in the service sector, and temporary workers are typically employed in firms with less than three thousand dependents (Jones and Urasawa, 2013).

This dualism stems from the high protection afforded regular workers, which leads firms to hire less costly non-regular workers. The latter are not provided with adequate training, which negatively impacts productivity. Moreover, because of high wage costs due to the seniority-based wage system (with the length of tenure in firms peaking at about age 50), many firms tend to push workers to retire before their mandatory retirement ages (which averaged 57 years in 2010), either through providing them less favorable working conditions (such as undesirable jobs) or through pecuniary incentives. Given the low pension replacement rate, such workers tend to become non-regular workers or self-employed in low productivity service industries.

While Korea's labor market duality has some positive aspects (first, it has contributed to keeping unemployment low; second, almost 50 percent of non-regular workers are voluntarily so, with a significant part of them accepting part-time contracts to balance work with other activities and to benefit from more flexible working hours), there are significant economic costs associated with labor market dualism. First, a lower share of non-regular workers (who are typically more sensitive to business cycle fluctuations) makes the labor market more resilient to demand shocks. Second, high dualism (in the form of a high share of non-regular workers) reduces the incentives of firms for investing in on-the-job training and other human capital accumulation practices for a large share of their employees, thereby reducing productivity.11) Third, labor market dualism, by

11) Empirical evidence suggests that labor market duality typically reduces productivity growth (Dolado et al. 2011; Damiani et al. 2011). 
increasing inequality 12), may also reduce macro-stability and limit the prospects for sustained high potential growth (IMF, 2013). Therefore, reducing the labor market dualism in Korea is important not only for addressing income inequality but also for promoting job stability and fostering productivity.

Which policies can help to reduce labor market dualism? A first priority is to reduce the relatively high degree of employment protection for regular workers, which provides an incentive for firms to hire workers on non-regular bases in order to reduce their labor costs. ${ }^{13)}$ In this context, policies aimed at reducing working hours (currently among the highest in OECD countries) could facilitate the acceptance of a reduction in employment protection. Second, raising the age set by firms for mandatory retirement and re-modulating the seniority-based wage system will be keys to reducing the incentives for firms to push workers to early retirement and to non-regular contracts. Third, improving social coverage for non-regular workers would reduce the labor cost gap between regular and non-regular workers, and thereby the incentive for firms to hire workers on non-regular bases, while increasing productivity by the enhancement of job security. Fourth, broadening the access to training opportunities for non-regular workers, which are typically not provided by firms, is important for fostering productivity at the aggregate level.

\section{Conclusions}

After a period of exceptional growth, Korean economic growth has gradually slowed since the mid-1990s. Although this slowdown in growth has not translated into rising unemployment rates (which have continued to decline and are among the lowest among OECD countries), labor market segmentation and the underemployment

12) Koske et al. (2011) find that Korea is one the few OECD countries where income inequality originates mostly due to duality in the labor market.

13) Empirical evidence based on international experience suggests that reducing employment rigidities for regular workers, while improving job protection for non-regular workers, can significantly reduce labor market dualism (Nunziata and Staffolani, 2007; Jaumotte, 2011; Aoyagi and Ganelli, 2013). 
of some segments of the population (notably, youth and women) are important labor market challenges and factors contributing to lower potential growth. Addressing these problems requires a comprehensive and well-sequenced set of structural reforms, which are summarized as follow:

\section{Boosting female labor force participation}

- increase investment in public childcare and childcare benefits;

- improve the work-life balance by facilitating more part-time work opportunities;

- make the tax treatment of second earners in households more neutral compared with that of single earners;

- address labor market dualism to improve job opportunities for women.

\section{Increasing youth employment}

- reduce skill mismatches by enhancing technical vocational education and training, including job-search techniques in school curricula by improving young people's access to information on career opportunities and reducing the lack of information available to youth as well as to SMEs;

- address labor market dualism to improve job opportunities for youth.

\section{Reducing labor market dualism}

- increase the age set by firms for mandatory retirement and re-modulate the seniority-based wage systems to reduce the incentives for firms to push workers into early retirement and non-regular contracts;

- reduce the relatively high degree of employment protection given for regular workers, to reduce the incentives for firms to hire workers on non-regular bases;

- broaden the access to training opportunities for non-regular workers, including via strengthening of targeted educational policies, and promote their transitions to regular employment;

- improve social coverage for non-regular workers, to reduce the incentives for firms to hire non-regular workers and improve job security. 
Our results suggest that the benefits of comprehensive structural reforms are likely to be considerable over the medium term. In particular, comprehensive policy reforms (such as: making the tax treatment of second earners in households compared with that of single earners more neutral; increasing childcare benefits; and facilitating more part-time work opportunities) aimed at reducing labor market distortions that inhibit labor force participation could lead to an increase in female participation rates of about 8 percentage points over the medium term, which would reduce by one-third the gap between the rates of male and female participation. Similarly, policy actions-including targeted educational policies and retraining programs-bringing skill mismatches back onto a downward path before 2005 can increase youth employment rates by 0.6 percentage points per year, which would boost the youth employment rate back to its pre-Asian crisis level within 10 years. Finally, reforms aimed at reducing labor market duality are likely to further enhance economic growth by boosting employment rates for youth and women and by increasing productivity at the sectoral (mostly services) and aggregate levels.

Addressing labor market duality and low participation is therefore a key priority for achieving sustained and inclusive growth, and the recent and ongoing policy actions launched by the authorities are important steps in this direction. Indeed, the government has a broad reform agenda for tackling labor market duality and boosting the employment rate to 70 percent by 2017 . Its " 70 Percent Roadmap" shifts the focus of job creation from the current male, manufacturing and conglomerate orientations toward females, services and SMEs. It also focuses on increasing youth and aged employment, improving the work-life balance by cutting the long working hours and expanding social insurance, including through subsidizing low-income employees of SMEs, eliminating discrimination for non-regular workers, and increasing the mobility between regular and non-regular workers. 


\section{References}

Aoyagi, Chie and Andrea Ganelli (2013), "The Path to Higher Growth: Does

Revamping Japan's Dual Labor Market Matter?” IMF Working Paper 13/202, International Monetary Fund.

Autor, D. H., F. Levy, and R. J. Murnane (2003), “The Skill Content of Recent Technological Change: An Empirical Exploration," Quarterly Journal of Economics, Vol. 118, No. 4, pp. 1279-1333.

Bernal-Verdugo, Lorenzo E., Davide Furceri, and Dominique M. Guillaume (2013), “Crises, Labor Market Policy, and Unemployment," Journal of Comparative Economics (forthcoming).

Damiani, Mirella, Fabrizio Pompei, and Andrea Ricci (2011), "Temporary Job Protection and Productivity Growth in EU Economies," Quaderni del Dipartimento di Economia, Finanza e Statistica 87/2011, University of Perugia. Dolado, Juan Jóse, Salvador Ortigueira, and Rodolfo Stucchi (2011), "Does Dual Employment Protection Affect TFP? Evidence from Spanish Manufacturing Firms," Economics Working Papers 11-37, Charles III University of Madrid.

Estevao, Marcello M. and Evridiki Tsounta (2011), "Has the Great Recession Raised U.S. Structural Unemployment?” IMF Working Paper 11/105, International Monetary Fund.

IMF (2013), "Jobs and Growth: Analytical and Operational Considerations for the Fund." Available via the Internet: www.imf.org/external/np/pp/eng/2013/ 031413.pdf.

Jain-Chandra, Sonali and Longmei Zhang (2014), "How can Korea Boost Potential

Output to Ensure Continued Income Convergence?" IMF Working Paper 14/54, International Monetary Fund.

Jaumotte, Florence (2003), "Labour Force Participation of Women: Empirical

Evidence on the Role of Policy and Other Determinants in OECD Countries,"

OECD Economic Studies, No. 37, OECD.

Jaumotte, Florence (2011), "The Spanish Labor Market in a Cross-Country Perspective," IMF Working Paper 11/11, International Monetary Fund.

Jones, Randall, and Satoshi Urasawa (2013), "Labor Market Policies to Promote 
Growth and Social Cohesion in Korea," OECD Economics Department Working Papers, No. 1068, OECD.

Koske, Isabelle, Jean-Marc Fournier, and Isabelle Wanner (2011), "Less Income Inequality and More Growth-Are They Compatible?: Part 2. The Distribution of Labour Incomes," OECD Economics Department Working Papers, No. 925, OECD.

Nunziata, Luca, and Stefano Staffolani (2007), "Short-term Contracts Regulations and Dynamic Labor Demand: Theory and Evidence," Scottish Journal of Political Economy, Vol. 54, No. 1.

Peters, D. (2000), "Manufacturing in Missouri: Skills-Mismatch, ESA-0900-2," Research and Planning, Department of Economic Development. 


\section{Appendix I. Skill Intensities of Industries in Korea}

\begin{tabular}{|c|c|c|c|}
\hline $\begin{array}{l}\text { KSIC } \\
\text { Industry } \\
\text { Code }\end{array}$ & Industry & $\begin{array}{c}\text { Skill } \\
\text { intensity }\end{array}$ & $\begin{array}{l}\text { Skill } \\
\text { Demand } \\
\text { Category }\end{array}$ \\
\hline 1 & Agriculture & 2.184 & M \\
\hline 2 & Forestry & 2.393 & M \\
\hline 5 & Fishing & 1.921 & L \\
\hline 10 & $\begin{array}{l}\text { Mining of Coal, Crude Petroleum and Natural Gas, Uranium } \\
\text { and Thorium Ores }\end{array}$ & 1.503 & $L$ \\
\hline 11 & Mining of Metal Ores & 1.677 & $\mathrm{~L}$ \\
\hline 12 & Mining of Non-metallic Minerals, Except Fuel & 2.016 & L \\
\hline 15 & Manufacture of Food Products and Beverages & 1.999 & L \\
\hline 16 & Manufacture of Tobacco Products & 2.231 & M \\
\hline 17 & Manufacture of Textiles, Except Sewn Wearing apparel & 1.979 & L \\
\hline 18 & Manufacture of Sewn Wearing Apparel and Fur Articles & 2.082 & M \\
\hline 19 & $\begin{array}{l}\text { Tanning and Dressing of Leather, Manufacture of Luggage } \\
\text { and Footwear }\end{array}$ & 2.004 & $\mathrm{~L}$ \\
\hline 20 & $\begin{array}{l}\text { Manufacture of Wood and of Products of Wood and Cork, } \\
\text { Except Furniture; Manufacture of Articles of Straw and Plaiting } \\
\text { Materials }\end{array}$ & 1.984 & $L$ \\
\hline 21 & Manufacture of Pulp, Paper and Paper Products & 2.061 & M \\
\hline 22 & Publishing, Printing and Reproduction of Recorded Media & 2.489 & $\mathrm{H}$ \\
\hline 23 & $\begin{array}{l}\text { Manufacture of Coke, Refined Petroleum Products and } \\
\text { Nuclear Fuel }\end{array}$ & 2.391 & M \\
\hline 24 & Manufacture of Chemicals and Chemical Products & 2.321 & M \\
\hline 25 & Manufacture of Rubber and Plastic Products & 2.066 & M \\
\hline 26 & Manufacture of Other Non-metallic Mineral Products & 2.056 & M \\
\hline 27 & Manufacture of Basic Metals & 1.999 & L \\
\hline 28 & $\begin{array}{l}\text { Manufacture of Fabricated Metal Products, Except Machinery } \\
\text { and Fumiture }\end{array}$ & 2.062 & M \\
\hline 29 & Manufacture of Other Machinery and Equipment & 2.166 & M \\
\hline 30 & Manufacture of Computers and Office Machinery & 2.360 & M \\
\hline 31 & Manufacture of Electrical Machinery and Apparatuseses n.e.c. & 2.151 & M \\
\hline 32 & Manufacture of Electronic Components, Radio, Television and & 2.261 & M \\
\hline 33 & $\begin{array}{l}\text { Manufacture of Medical, Presision and Optical Instruments, } \\
\text { Watches and Clocks }\end{array}$ & 2.253 & M \\
\hline 34 & Manufacture of Motor Vehicles, Trailers and Semitrailers & 2.043 & $\mathrm{~L}$ \\
\hline 35 & Manufacture of Other Transport Equipment & 2.087 & M \\
\hline 36 & Manufacture of Furniture; Manufacturing of Articles n.e.c. & 2.017 & $\mathrm{~L}$ \\
\hline 37 & Recycling & 1.897 & $\mathrm{~L}$ \\
\hline 40 & Electricity, Gas, Steam and Hot Water Supply & 2.454 & $\mathrm{H}$ \\
\hline
\end{tabular}




\begin{tabular}{|c|c|c|c|}
\hline $\begin{array}{c}\text { KSIC } \\
\text { Industry } \\
\text { Code }\end{array}$ & Industry & $\begin{array}{c}\text { Skill } \\
\text { intensity }\end{array}$ & $\begin{array}{c}\text { Skill } \\
\text { Demand } \\
\text { Category }\end{array}$ \\
\hline 41 & Collection, Purification and Distribution of Water & 2.777 & $\mathrm{H}$ \\
\hline 45 & General Construction & 2.559 & $\mathrm{H}$ \\
\hline 46 & Special Trade Construction & 2.249 & M \\
\hline 50 & $\begin{array}{l}\text { Sale of Motor Vehicles and Motorcycles; Retail Sale of } \\
\text { Automotive Fuel }\end{array}$ & 2.255 & M \\
\hline 51 & $\begin{array}{l}\text { Wholesale Trde and Commission Trade, Except of Motor } \\
\text { Vehicles and Motorcvcles }\end{array}$ & 2.424 & $\mathrm{H}$ \\
\hline 52 & Retail Trade, Except Motor Vehicles and Motorcycles & 2.243 & M \\
\hline 55 & Hotels and Restaurants & 2.024 & $\mathrm{~L}$ \\
\hline 60 & Land Transport; Transport Via Pipelines & 1.899 & L \\
\hline 61 & Water Transport & 2.362 & M \\
\hline 62 & Air Transport & 2.677 & $\mathrm{H}$ \\
\hline 63 & $\begin{array}{l}\text { Supporting and Auxiliary Transport Acvivities; Activities of } \\
\text { Travel Aqencies }\end{array}$ & 2.265 & M \\
\hline 64 & Post and Telecommunications & 2.426 & $\mathrm{H}$ \\
\hline 65 & Financial Institutions, Except Insurance and Pension Fundina & 2.421 & $\mathrm{H}$ \\
\hline 66 & $\begin{array}{l}\text { Ilnsurance and Pension Funding, Except Compulsory Social } \\
\text { Security }\end{array}$ & 2.669 & $\mathrm{H}$ \\
\hline 67 & Activities Auxiliary to Financial Intermediation & 2.681 & $\mathrm{H}$ \\
\hline 70 & Real Estate Activities & 2.036 & L \\
\hline 71 & Renting of Machinery and Equipment without Operator and of & 2.312 & M \\
\hline 72 & Computer and Related Activities & 2.778 & $\mathrm{H}$ \\
\hline 73 & Research and Development & 2.780 & $\mathrm{H}$ \\
\hline 74 & Professional, Scientific and Technical Services & 2.591 & $\mathrm{H}$ \\
\hline 75 & Business Supports Services & 2.120 & M \\
\hline 80 & Education & 2.690 & $\mathrm{H}$ \\
\hline 85 & Human Health and Veterinary Activities & 2.243 & M \\
\hline 86 & Social Work Activities & 2.276 & M \\
\hline 87 & Motion Picture, Broadcasting and Performing Arts Industries & 2.583 & $\mathrm{H}$ \\
\hline 88 & Other Recreational, Cultural and Sporting Activities & 2.253 & M \\
\hline 90 & Sewage and Refuse Disosal, Sanitation and Similar Activities & 1.895 & $\mathrm{~L}$ \\
\hline 91 & Membership Organizations n.e.c. & 2.534 & $\mathrm{H}$ \\
\hline 92 & Maintenance and Repair Services & 2.067 & M \\
\hline \multirow[t]{5}{*}{93} & Other Services Activities & 2.048 & $\mathrm{~L}$ \\
\hline & Mean & 2.237 & \\
\hline & Std Dev & 0.276 & \\
\hline & Mean+0.67*Std Dev & 2.422 & \\
\hline & Mean-0.67*Std Dev & 2.053 & \\
\hline
\end{tabular}




\section{<Abstract in Korean>}

\section{Mai Dao*, Davide Furceri*, 황지수**, 김미연***, 김태정****}

우리나라는 $\mathrm{OECD}$ 국가들과 비교해 볼 때 여성 및 청년층의 고용률이 낮고 정규직-비정규직 간 이원화 정도가 심해 이와 관련된 노동시장 구조개혁을 통한 잠재성장률을 제고할 수 있는 여지가 크다. 본고는 여성의 경제활동참여율, 노동 시장 미스매치(mismatch) 및 노동시장 이원화 현황을 파악하고 실증분석을 통해 어떤 정책이 필요한지 살펴보았다. $\mathrm{OECD}$ 국가들의 패널분석 결과, 여성경제 활동참여율은 2 차 소득원에 대한 실질세율 조정, 시간제 근로에 대한 세제혜택 확대, 육아관련 보조금 개선 등으로 향상시킬 수 있는 것으로 나타난다. 미스매치와 경기변수 등을 설명변수로 하여 고용률 회귀식을 추정한 결과, 노동시장 미스 매치를 줄이면 고용률이 높아지는 효과가 뚜렷한 것으로 분석된다. 노동시장의 이원화를 완화하기 위해서는 정규직과 비정규직에 대한 고용보호 격차를 축소, 연공서열식 임금제도 개편, 비정규직에 대한 사회보장 혜택 및 직업훈련 기회 확대가 필요할 것으로 보인다.

* IMF 아태국(Asia and Pacific Department)

** 퇴직직원으로서 본 연구는 한국은행 근무시 완료되었음(현재 한국외국어대학교 재직)

*** 퇴직직원으로서 한국은행 재직시 본연구에 참여

**** 한국은행 경제연구원

연구내용은 집필자의 개인의견이며 한국은행의 공식견해와는 무관합니다. 따라서 본 논문의 내용을 보도 하거나 인용할 경우에는 집필자명을 반드시 명시하여 주시기 바랍니다. 